INTERNATIONAL CONFERENCE ON THE SAFETY OF LIFE AT SEA.

THE International Conference on the Safety of Life at Sea was opened by the President of the Board of Trade on November 12, at the Foreign Office, in the presence of delegates from Germany, the United States of America, Australia, AustriaHungary, Belgium, Canada, Denmark, Spain, France, Great Britain, Italy, Norway, Netherlands, Russia, Sweden, and New Zealand.

After offering a warm welcome to the delegates on behalf of the British Government, and an expression of their gratification at the cordial manner their invitation to the conference had been accepted, Mr. Buxton alluded to the importance of the task before them, and ventured on the opinion that few international conferences had had a greater and nobler work entrusted to them.

With regard to the questions to be discussed, he considered that they could be divided broadly into five heads. These may be summarised as follow:(r) Is it possible to eliminate the liability to founder by constructional arrangements? (2) In the event of collision, fire, and other accidents, what life apparatus are required to minimise disaster and to save life? (3) What organisations are best to ensure the effective and expeditious handling of lifesaving appliances on board the ship herself and the rescuing ship? (4) How can assistance from another ship or from shore be most quickly and effectively invoked and obtained? (5) What measures can be taken on behalf of the ships to avert or diminish the risk of accident, under which head come the observation and reporting of ice and derelicts, storm and fog signals, and warnings, \&c.?

The President of the Board of Trade then read a message of cordial welcome to the delegates from the King, in which his Majesty referred to his personal experience as a sailor of many of the matters that would be considered by the conference, and to the special interest he took in the questions they were about to consider, affecting as they did the lives of so vast a number of his subjects.

An interesting speech from Dr. von Koerner, the chief German delegate, followed.

Lord Mersey, who was unanimously elected president, after thanking the delegates for the honour they had conferred upon him, pointed out that while means have to be taken to secure comparative immunity from risk, the practical requirements of business must be borne in mind. "Perfection," he said, "can sometimes be reached at too great a cost. But while remembering these two considerations, I would suggest that where doubt exists, the tendency should always lean towards the line of safety rather than towards the line of economy." Lord Mersey went on to say that increased cost incurred in the interest of safety will be cheerfully met by the public, who, after all, are those who have to pay.

After luncheon at the Foreign Office, Sir Edward Grey and M. Guernier, the chief French delegate, were the principal speakers. The former remarked that, though international, the conference caused no anxiety diplomatically, because, unlike some which arouse the rivalry of nations, it sprang from one of those human tragedies in history which only cause sympathy among the nations.
AGRICULTURAL ENTOMOLOGY IN THE UNIVERSITY OF MANCHESTER.

THE new laboratory for research work in agricultural entomology in the University of Manchester is situated at the top of the north-east corner of the University buildings in Oxford Road. Its position gives easy access to the general zoological laboratories on the floor below and to the collections of the Manchester Museum in the same building. It is a lofty room, $5^{8} \mathrm{ft}$. in length by $28 \mathrm{ft}$. wide, with accommodation for five or six persons engaged in original investigations. The windows under which the working benches are placed face due north, and two large skylights in the sloping roof give illumination on the south side of the room. Leading out of the main laboratory there is a private room for the reader in agricultural entomology, $I_{7} \mathrm{ft}$. by $\mathrm{I}_{7} \mathrm{ft}$., with a staircase leading to a working place raised above the floor level.

At a distance of about a mile from the University and on the main tram route, there is an experimental field with glass houses and a small laboratory, where the insectaria can be erected, trees planted, and other arrangements made for breeding and observing insect 
for the M.Sc. degree after a course of two years' rescarch work in the University.

The new laboratory was opened on November I $_{3}$ by Sir Sydney Olivier, the Permanent Secretary of the Board of Agriculture and Fisheries, in the absence of Mr. Walter Runciman, the President of the Board, who was detained in London by a meeting of the Cabinet Council. At the opening ceremony, Dr. Imms gave a short sketch of the aims and scope of agricultural entomology, and Sir Sydney Olivier, in declaring the laboratory open, explained the policy of the Board as regards the endowment of the universities and agricultural institutions for research work in agricultural science.

At the conclusion of the ceremony a number of exhibits of the research work done in the department and of the apparatus used in entomological investigations was shown to the visitors in the zoological laboratories and museum.

s. J. HICKSON.

\section{THE PASSIVITY OF METALS}

A GROUP of eight papers brought together with the view of setting forth every aspect of "passivity" as it presents itself to those now actively engaged in working out a satisfactory explanation of this most difficult and elusive subject, was discussed at the meeting of the Faraday Society on November $\mathbf{I} 2$.

The theoretical importance of passivity lies in the fact that it is in all probability so closely bound up with the fundamental mechanism of electrolvtic action that a proper understanding of its cause will go far towards clearing away many of the difficulties which still surround the simple processes of anodic solution and kathodic deposition. It has further an important practical bearing on corrosion, for if this be an electrolytic action, a non-corrodible metal and a passive metal are, anyhow within certain limits, synonymous terms. The very idea of the connection suggests a line of research on non-corrodible alloys that may lead to most fruitful results. But if the subject is important, it is no less perplexing. At present two theories, in many respects diametrically opposed to one another, would appear to hold the field, one of which, broadly speaking, ascribes passivity to the presence of oxygen in some form or another, and the other to hydrogen. It may be added that the advocates of each theory point to an experimentum crucis claimed to prove the impossibility of its rival as a satisfactory explanation of all the phenomena which have been observed.

While attention was concentrated on the original observation made in I79o by Keir, that iron became "passive" or indissoluble after plunging into strong nitric acid, the simple mechanical explanation that the change of state was due to a close film of protective oxide no doubt seemed all-sufficient. It was only when passivity was studied as an electrolytic phenomenon, as an example of anodic polarisation by which the passive metal rises higher in the electrolytic scale towards the "noble" metals than it was in its active state, that a broader interpretation was called for, and hence was put forward Le Blanc's fruitful conception that the retarded anodic action was chemical and not mechanical in its origin, and that it must be explained as arising from the diminished reaction-relocity of some chemical process taking place at the anode. This conception is now universally adopted in the consideration of passivity phenomena; the only question arising is, What is the reaction the velocity of which is diminished when metals become passive?

To this question the following answers were given in the papers presented for discussion.

NO. 2299 , VOL. 92$]$
(I) Adopting the current view of Nernst that electrode potential is a result of the formation of metallic ions when the electrode is placed into an electrolyte, Dr. G. Grube supposes this action to be retarded under conditions known as passive by the formation of an alloy of anode surface and oxygen, which has a lower solution pressure than the pure metal. Such retardation of anodic action is known to take place when a platinum anode is used in the electrolysis of halogen salts, and for the self-same reason, and aralogous kathodic retardation was likervise shown to exist by Dr. Grube; for example, when zinc and hydrogen are deposited simultaneously with iron. Much the same theory was developed by Dr. D. Reichinstein direct from the Nernst formula, and experimental support was given to the theory by Dr. $\mathrm{H}$. S. Allen, who showed that the photo-electric behaviour of iron-its property of losing negative electricity under the action of light--which from considerations of "fatigue" is believed also to be due to the state of the gaseous film on the metal, increases or diminishes in intensity according as the iron is in the active or passive state.

(2) In order to take into consideration the specific properties of the electrolyte anion some investigators are now reverting to the old Grotthus vicw of electrolysis that the primary action at the anode is not the formation of metallic ions, but a discharge of negative ions (anions). Prof. Leblanc, however, further supposes that the anion is hydrated, and that passivity is merely the retardation of the reversible reaction, ion-hydrate $\rightleftarrows$ ion + water. Prof. E. Schoch also adopts the theory of primary anion discharge, but impressed by Dr. Günther Schulze's experiments on the structure of aluminium anode-films, he considers that under certain conditions of current density, temperature, \&c., there will be a diminished rate of reaction between anions and electrode owing to the formation on the latter of a film of oxide or oxygen. Neither of these theories, which seem to make gratuitous and unnecessary assumptions, were received with much favour.

(3) More attractive is the hydrogen theory stated in the paper presented by Prof. $G$. Schmidt, and supported by some ingenious and striking experiments. This supposes that the passive condition is normal, and that metals like iron and chromium are only rendered active by the diffusion through them of hydrogen, which acts as a catalyst and sets up local action. Possibly this is often the case, but it is doubtful whether the "hydrogenactivation" theory will explain all cases of passivity. In the end it may be found, as Dr. G. Senter said in the course of the discussion, that no one theory will cover every case of passivity, but the sense of the meeting was certainly in favour of either an oxygenfilm or an oxygen surface alloy as offering in most cases a satisfactory working hypothesis of the passive state.

\section{UNIVERSITY EDUCATION IN LONDON}

$T$ HE President of the Board of Education has sent to the Vice-Chancellor of London University an important letter in which he announces that the Government accepts in general the recommendations of the Royal Commission on University Education in London, and is prepared to act upon them. The letter is as follows:-

Board of Education, Whitehall, S.W., Nov. I2, I9I3.

DEAR Mr. Herringham,-I. I am very anxious that the position of the Government in regard to the proposed reconstitution of the University should be generally realised, and that discussion should not be 